\title{
Quality of Work Life - Development and Scale Validation for Textile Sectors in India
}

\author{
Vanishree Beloor, T S Nanjundeswaraswamy, Swamy D R
}

\begin{abstract}
Employee Retention is one of the challenging task faced by textile industries s today. To retain dexterous and adapted employees an acceptable $Q W L$ is the requirement by employees and this QWL is marked with intricate dimensions inclined by numerous alterable factors. QWL instrument was applied to their research by many researchers but all of them measure total variance of less than $60 \%$. Therefore it is through the current study that drives the components for a measuring tool that outfits textile sector. This is a survey based study carried out through questionnaires targeting 341 employees working in textile sector. It was then proceeded with analysis part containing EFA to minimize the number of items then followed by confirming the instrument through Confirmatory Factor Analysis (CFA) using SPSS16. In the light of defining interrelationships among the drawn components via EFA ,SEM was done using AMOS. The results of EFA came out with 6 marking dimensions that described $61 \%$ of the total variance. The instrument was validated and confirmed through CFA. The six components were Compensation, Work Environment, Relation and Co Operation, Job Security, Facilities and Training and Development which together summed up to total variance of 61 percent. All the necessary fit indices were satisfied with the acceptable range noting chi-square statistics of $3650.935(d f=351$ and $p=0.000)$, $\chi^{2} /$ df ratio $=10.40, G F I=0.910, A G F I=0.900, N F I=0.899, I F I=$ $0.950, C F I=0.908, T L I=0.902$ are more than 0.9 and $R M S E A=$ 0.071. A six factor QWL model with 27 items has construct validity. A reliable and valid tool was developed. This instrument is more useful to measure $Q W L$ in textiles.
\end{abstract}

Keywords : Confirmatory Factor Analysis, Exploratory Factor Analysis, Structural Equation Modelling, Textiles, Quality of Work Life,

\section{INTRODUCTION}

Indian Textile industries are gaining much attention now days due to their inability to provide Quality work life to workers. According to a report by Somo and the India Committee of the Netherlands (ICN)(2012) described working conditions in Indian textile factories as a ruining one for lower level employees working in this sector. Textiles industries are driving major work force in developing

Revised Manuscript Received on August 30, 2019.

* Correspondence Author

Vanishree Beloor*, Assistant Professor, Department of IEM, JSS Academy of Technical Education, Bangalore ,Email: vanishreeblr@gmail.com

Dr. T S Nanjundeswaraswamy, Associate Professor, Department of Mechanical Engineering, JSS Academy of Technical Education, Bangalore, Email: nswamy.ts@gmail.com, nswamy.ts@jssateb.ac.in

Dr. Swamy D R, Professor, Department of IEM, JSS Academy of Technical Education, Bangalore, Email:drswamydr@gmail.com

(c) The Authors. Published by Blue Eyes Intelligence Engineering and Sciences Publication (BEIESP). This is an open access article under the CC BY-NC-ND license (http://creativecommons.org/licenses/by-nc-nd/4.0/) countries like India, China and Bangladesh and these labor oriented industries are facing problems related to their retention rate and due to which topics related to their retention rate is becoming popular that are being considered for study. This sector has become the second largest employment provider after Agriculture in India. In spite of being so the working conditions in this sector are questioning and workers here are still fighting for their basic needs and human rights for which justice is a long awaited need. This need has led to the following study being carried out to provide a measuring instrument that quantifies the status of QWL in this sector.

Quality of Work Life is the standard of workers performing comfortably in an organization by satisfying their personal needs through the facilities provided to them by the management. Their level of involvement and commitment is increased by enhancing their QWL factors. This high level of involvement can be achieved by providing an employee the necessary benefits and making him more involved as a decision taker in major organizational matters. This means implementing policies and procedures that make an employee have a stress less work life bounded by the necessary benefits thereby providing them a Quality life. This not only benefits an employee but also employer as it has a direct effect on productivity. Therefore, the objectives set by an organization and its victory in relevant areas can be achieved only after needs at individual level are satisfied. For satisfying individual needs QWL concept has to be studied in which employees are given prime importance and conditions are better provided.

\section{LITERATURE REVIEW:}

Nanjundeswaraswamy and Swamy (2015) examined the association between QWL and styles of leadership at SMEs in and around Bengaluru region by considering the 9 components of QWL as Autonomy of work, Adequacy of resources, Compensation and Rewards, Facilities, Job satisfaction and Job Security, Organization culture and climate Work environment, Relation and co-operation, Training and Development under Transactional and Transformational styles of Leadership. Findings of the analysis divulges about a substantial rapport between Styles of leadership and QWL.

Akter and Banik (2018) studied employees status of QWL in RMG units at Bangladesh. The factors taken into account were career and growth opportunities, fair Payment, Job Security and safety, leave and holiday benefits, social and psychological support Work Environment, with the outcome that suggested saying ,Work Environment should be improved that is effecting the Quality of working life of employees. 


\section{Quality of Work Life - Development and Scale Validation for Textile Sectors in India}

Haque et al. (2015) assessed the Quality of Work Life of Employees in Garments at Dhaka, Bangladesh by considering the factors like career growth opportunity, compensation, informal relationship, job security, job design, and participation in decision making, working environment where in the results of the study disclosed that workers are impartial with the work environment providing them profits of Quality of Work Life.

Ellah Mejbel et al.(2013) explored the factors such as benefits and compensation, career development, cohesion of work and life, employee motivation , communication, employee motivation reward, job satisfaction, safety and security, top management involvement and revealed about the most frequent drivers used by previous studies are rewards, benefits, compensation, career development, communication, and safety and security whereas cohesion of work and life, employee motivation, job satisfaction, top management involvement are not frequently used by researchers.

Zare et al. (2012) evaluated the QWL in residents at seven infirmaries considering the factors such as diversity and flexibility in job, facilities, issues related to health and safety, salary of an employee, participating in decision making, management approach. The outcome of the study disclosed a positive response of employees regarding Attitude and expertisation of their seniors, conditions for promotion, professional training, and hygienic domestic zone at the infirm place.

Subhashini and Gopal (2013) measured the status of QWL of women employees in apparels in Coimbatore district of Tamilnadu by considering the elements such as co-worker relationship, Health and safety benefits, grievance handling procedure ,workload, Respect at work place, Satisfaction about feedback given, Training Working hours. The measurements concluded with the outcome of female population being more gratified with Grievance handling procedures, Work atmosphere, and job security measures and unhappy with the Salary, Health and Safety measures provided permitted leave.

Rose et al. (2006). envisaged QWL as career-related measurement and considered career satisfaction, career achievement and career balance for transnational companies and SME's in Malaysia. The outcome of the study specified the exogenous variables considered for the study are related with Quality of Work Life.

Hosmani and Shambhushankar (2014) revealed performance and Quality of work life (QWL) of employees in central Railways considering measurements of QWL as opportunities for career development, conditions at work place, welfare and safety measures with the outcome of the study stating job performance and job satisfaction level of employees are enhanced with acceptable measures of QWL programs

Swamy, Nanjundeswaraswamy, and Rashmi (2015). developed a QWL Scale by taking into account nine main dimensions namely Work Autonomy, Adequacy of resources, Compensation and Rewards, Job satisfaction and Job security, Facilities, Organization culture and climate, Relation and co-operation, Training and development, Work environment and validated instrument that showed satisfactory total variance.

Narehan et al.(2014) established association between QWL and QOL among personnel at transnational companies in Malaysia's Bintulu, Sarawak, by considering the factors of QWL as Work Environment, Job facets and QOL factors as employees emotional wellbeing, interpersonal relations, personal development, social inclusion that resulted in noteworthy relationship between QWL programs and QOL.

According to Rubel and Kee (2014) considered job satisfaction as forerunner of QWL and it is pointedly related with employee in-role performance. The measures of QWL were job character, compensation and benefits, behaviour of supervisor, balance between work life and personal life.

Daud, N. (2012) determined the relationship between Quality of Work Life and Organizational Commitment among employees. QWL measurements were Growth and Development, Pay benefits, Physical Environment, Participation, supervision and Work place combination. The findings indicated QWL level as favourable one and commitment to organization is moderate among employees. Rathamani and Ramchandra (2013) marked out the factors influencing QWL in garment sector Perundurai by making use of variables namely Job freedom and security , Motivational acumens, individual growth and more chances in career and conditions of work Environment that resulted in the fact that Motivational acumen is the chief feature impacting QWL of employees where as better pay benefits influenced employees efficiency.

According to Yadav and Khanna(2014) from their review of literature identified seven frequently used QWL components namely Development and Growth, commitment to organization, satisfaction in job,Pay and benefits, Supervision,Safety and healthy environment. The results of review revealed OCB, growth and profitability of organization are the factors that are not taken considered for study which may be used by future researchers.

Indumathy (2012) discovered the factors like work environment, attitude, job nature, ostudied Quality of Work Life among workers with special reference to textile industry in Tirupur district and found out that attitude, environment, opportunities, level of stress, career prospects and reward ,challenges, growth and development, work risk are chief components that impact QWL.

Ramachandran(2018) study aimed in discovering the elements of QWL of personnel in private companies of Ernakulum District. Results revealed policies of compensation, organization culture, career growth related opportunities lead to satisfaction of employees ensuring organizational productivity.

According to Kanakarathinam (2016) the status of QWL in textile firms of Tirupur district in Tamil Nadu and identified factors with low relationship such as job satisfaction and working conditions, incentives, development and encouragement, handling of grievances, training. Wheras Autonomy, Work life balance has low positive association with employee satisfaction and Wage structure shows a negative association with employee satisfaction.

Sinha(2012)considered factors of QWL such as complete direction and self-determination, innovative and expertised direction, direction of relationship-sustenance that played the most important role in fulfilling the wants of the personnel and how different facets are prioritized in management at intermediate level in employing, to bring up high quality of Working life. 
Dhamija, et al(2019) quantified job satisfaction using QWL factors in Banking sector such as Awareness about job and commitment, Satisfaction of Employees and persistance, adverse work Environment, Professed Job Instigators and Organizational Culture whereas measures of job satisfaction are Colleagues , Conditional Rewards , Communication ,pay, upgradement in job, Management, Benefits, , Functioning Procedures, Nature of Work. The results of the study showed that adverse work environment is not positively linked with job satisfaction.

Elisaveta (2006) surveyed the relationship among perceptions of QWL components like experience in work, job attributes, work environment and job satisfaction. The outcome of the study showed a noteworthy association between QWL and JS.

Kang and Deepak (2013) study analysed level of QWL between the veterinarians of Punjab. The results declared that 'Economic importance, Work place communality, 'Work constitutionalism, job pride, Permitting present performance and future requirements, Security and Safety, unbiased management of supervisors, 'Working space and conditions, 'problem solving abilities are positively associated with
QWL where as 'Job nature' is negatively linked with QWL and creative and perplexing work and uninformed users do not show any association with QWL.

Roopa and Narayanan (2014) assessed the sense of QWL, detailed out the magnitudes of QWL based on replicas and previous studies in Information Technology Industry in India. The magnitides of QWL are Reward, satisfaction in job, Human Relation, Condition of work, handling of grievances, nature of competance, Stress and welfare facilities that resulted in saying that QWL in Information Technology sector is provocating employees and companies.

Nayak et al (2015) apertured by appraising the conciliating role of Quality of Work Life between authorization at workplace and commitment of employees in hospital employees in Odisha. The results of the study clarified the fact about QWL partially arbitrating between authorization at work place and employee commitment. The study guaranteed that workplace authorization can accelerate employee perception and elevate their level of obtained QWL.

Table:1 Dimensions of Quality of Work Life used by different researchers

\begin{tabular}{|c|c|c|}
\hline Author & Components & Outcomes \\
\hline $\begin{array}{l}\text { Nanjundeswaraswamy. Swamy } \\
\text { (2015) }\end{array}$ & $\begin{array}{ll}\text { - } & \text { Adequacy of resources } \\
\text { - } & \text { Autonomy of work, } \\
\text { - } & \text { Facilities, } \\
\text { - } & \text { Job satisfaction and Job } \\
\text { - } \quad \text { Security, } \\
\quad \text { Organization culture and } \\
\text { - } \quad \text { Relationate, } \\
\text { - Training and co-operation, } \\
\text { - Work environment, }\end{array}$ & $\begin{array}{l}\text { Substantial link with the components } \\
\text { and QWL. }\end{array}$ \\
\hline Akter and Banik (2018) & $\begin{array}{ll}\text { - } & \text { career and growth } \\
\text { - } & \text { Fair Payment } \\
\text { - } & \text { Job Security } \\
\text { - } & \text { leave and holiday benefits } \\
\text { - } & \text { safety } \\
\text { - } & \text { Social and Psychological } \\
\text { - } & \text { Support. } \\
\text { Work Environment }\end{array}$ & $\begin{array}{l}\text { Work Environment should be improved } \\
\text { that is affecting the Quality of working } \\
\text { life of employees. }\end{array}$ \\
\hline Haque et al. (2015) & $\begin{array}{ll}\text { - } & \text { Career growth opportunity } \\
\text { - } & \text { Compensation } \\
\text { - } & \text { Informal relationship } \\
\text { - } & \text { Job design } \\
\text { - } & \text { Job security } \\
\text { - } & \text { Participation in decision } \\
& \text { making } \\
\text { - } & \text { Work load } \\
\text { - } & \text { Working environment }\end{array}$ & $\begin{array}{l}\text { Adequate feeling towards their QWL } \\
\text { initiatives provided by management in } \\
\text { their work environment. }\end{array}$ \\
\hline
\end{tabular}

Blue Eyes Intelligence Engineering

\& Sciences Publication 
Quality of Work Life - Development and Scale Validation for Textile Sectors in India

\begin{tabular}{|c|c|c|}
\hline Author & Components & Outcomes \\
\hline Ellah Mejbel et al.(2013) & $\begin{array}{ll}\text { - } & \text { Benefits and Compensation } \\
\text { - } & \text { Career Development } \\
\text { - } & \text { Cohesion of work and life } \\
\text { - } & \text { Communication } \\
\text { - } & \text { Employee Motivation } \\
\text { - } & \text { Job Satisfaction } \\
\text { - } & \text { Reward } \\
\text { - } & \text { safety and security } \\
\text { - } & \text { Top management involvement } \\
\end{array}$ & $\begin{array}{l}\text { Frequently used components of QWL } \\
\text { are safety and security, communication, } \\
\text { career development, payments, profits } \\
\text { and compensation other drivers that are } \\
\text { limitedly used are top management } \\
\text { cohesion of work and life, employee } \\
\text { motivation, participation, job } \\
\text { satisfaction. }\end{array}$ \\
\hline Zare et al. (2012) & $\begin{array}{ll}\text { - } & \text { Employee salary, } \\
\text { - } & \text { Facilities, } \\
\text { - } & \text { Health and Safety issues, } \\
\text { - } & \text { Job Diversity and Flexibility. } \\
\text { - } & \text { Management approach and } \\
\text { - } & \text { Participating in Decision } \\
& \text { Making, } \\
\end{array}$ & $\begin{array}{l}\text { Residents were satisfied with the } \\
\text { promotion facilities, training, Job } \\
\text { knowledge and behaviour of their } \\
\text { supervisors. }\end{array}$ \\
\hline Subhashini and Gopal (2013) & $\begin{array}{ll}\text { - } & \text { grievance handling procedure } \\
\text { - } & \text { Health and Safety measures } \\
\text { - } & \text { Opinion about working hours } \\
\text { - } & \text { Opinion about workload } \\
\text { - } & \text { Relationship with co-worker } \\
\text { - } & \text { Respect at work place } \\
\text { - } & \text { Satisfaction about feedback } \\
& \text { given } \\
\text { - } & \text { Training }\end{array}$ & $\begin{array}{l}\text { Analysis depicted about women } \\
\text { employees of the garment factory being } \\
\text { satisfied with Grievance handling } \\
\text { procedures, Work atmosphere, job } \\
\text { security measures and were dissatisfied } \\
\text { with the Salary, Health and Safety } \\
\text { measures, permitted leave. }\end{array}$ \\
\hline Rose et al. (2006). & $\begin{array}{l}\text { - } \\
\text { - } \\
\text { - } \\
\text { career areer contentment, } \\
\text { career stability }\end{array}$ & $\begin{array}{l}\text { contentment, attainment and stability in } \\
\text { career are associated with Quality of } \\
\text { Work Life. }\end{array}$ \\
\hline $\begin{array}{l}\text { Hosmani and Shambhushankar } \\
\text { (2014) }\end{array}$ & $\begin{array}{ll}\text { - } & \text { career development } \\
& \text { opportunities } \\
\text { - } & \text { safety measures, } \\
\text { - } & \text { welfare practices, } \\
\text { - } & \text { working conditions }\end{array}$ & $\begin{array}{l}\text { Employee job satisfaction and } \\
\text { performance level were improved by } \\
\text { providing acceptable measures of QWL } \\
\text { programs. }\end{array}$ \\
\hline $\begin{array}{l}\text { Swamy, Nanjundeswaraswamy, } \\
\text { and Rashmi (2015) }\end{array}$ & $\begin{array}{ll}\text { - } & \text { Adequacy of resources } \\
\text { - } & \text { Autonomy of work, } \\
\text { - } & \text { Compensation and Rewards, } \\
\text { - } & \text { Facilities, } \\
\text { - } & \text { Job satisfaction } \\
\text { - } & \text { Job security, } \\
\text { - } & \text { Organization culture and } \\
\text { - } & \text { climate } \\
\text { - } & \text { Training and development, } \\
\text { - } & \text { Work environment, }\end{array}$ & $\begin{array}{l}\text { Developed and validated QWL scale } \\
\text { that showed suitable total variance. }\end{array}$ \\
\hline Narehan et al.(2014) & $\begin{array}{ll}\text { - } & \text { Work Environment } \\
\text { - } & \text { Job facets }\end{array}$ & $\begin{array}{l}\text { A substantial association between QWL } \\
\text { programs and QOL. }\end{array}$ \\
\hline Rubel and Kee (2014) & $\begin{array}{l}\text { - } \quad \text { compensation and benefits } \\
\text { - } \quad \text { Job character. } \\
\text { - } \quad \text { supervisor behaviour } \\
\text { - } \quad \text { work life balance }\end{array}$ & $\begin{array}{l}\text { QWL was significantly related to } \\
\text { employee in-role performance when job } \\
\text { satisfaction was a forebear of QWL. }\end{array}$ \\
\hline
\end{tabular}




\begin{tabular}{|c|c|c|}
\hline Author & Components & $\begin{array}{r}\text { Outcomes } \\
\end{array}$ \\
\hline Daud(2012) & $\begin{array}{ll}\text { - } & \text { Growth and Development } \\
\text { - } & \text { Participation } \\
\text { - } & \text { Physical Environment } \\
\text { - } & \text { supervision and Pay benefits. } \\
\text { - } & \text { Work place integration }\end{array}$ & $\begin{array}{l}\text { QWL is strongly associated and } \\
\text { commitment to organization is moderate } \\
\text { among staff. }\end{array}$ \\
\hline $\begin{array}{l}\text { Rathamani and Ramchandra } \\
\text { (2013) }\end{array}$ & $\begin{array}{l}\text { - } \text { Job freedom and security } \\
\text { - } \quad \text { Motivational insights } \\
\text { - } \quad \text { Personal growth and career } \\
\text { opportunities } \\
\text { - } \quad \text { Working Environment, }\end{array}$ & $\begin{array}{l}\text { QWL of employees is impacted by } \\
\text { Motivational visions and Higher } \\
\text { compensation that enhances the output } \\
\text { and efficiency of workforce. }\end{array}$ \\
\hline Yadav and Khanna(2014) & $\begin{array}{ll}\text { - } & \text { Growth and development } \\
\text { - } & \text { Job satisfaction } \\
\text { - } & \text { Organisation commitment } \\
\text { - } & \text { Pay and benefits } \\
\text { - } & \text { Safety and healthy } \\
\text { environment } \\
\text { - } \quad \text { Supervision } \\
\end{array}$ & $\begin{array}{l}\text { Organization's advancement, } \\
\text { success, and OCB are the factors that } \\
\text { are not taken considered for study which } \\
\text { may be used by future researchers. }\end{array}$ \\
\hline Indumathy (2012) & $\begin{array}{ll}\text { - } & \text { Attitude } \\
\text { - } & \text { career prospects, challenges } \\
\text { - } & \text { environment, opportunities } \\
\text { - } & \text { growth and development and } \\
\text { - } & \text { nature of job } \\
\text { - } & \text { people } \\
\text { - } & \text { risk involved in the work and } \\
& \text { reward } \\
\text { - } & \text { stress level }\end{array}$ & $\begin{array}{l}\text { Identified these as important } \\
\text { measurements of QWL. }\end{array}$ \\
\hline Ramachandran(2018) & $\begin{array}{ll}\text { - } & \text { Advancement in career } \\
\text { - } & \text { Payment rules } \\
\text { - } & \text { Values of organization } \\
& \text { appropriate }\end{array}$ & $\begin{array}{l}\text { Values of organization, appropriate } \\
\text { Payment rules, Advancement in career } \\
\text { are important factors that impact QWL } \\
\text { of employees. }\end{array}$ \\
\hline Kanakarathinam (2016) & $\begin{array}{ll}\text { - } & \text { Autonomy } \\
\text { - } & \text { development ,encouragement } \\
\text { - } & \text { grievance redressal } \\
\text { - } & \text { incentives } \\
\text { - } & \text { job satisfaction } \\
\text { - } & \text { training } \\
\text { - } & \text { Pay structure } \\
\text { - } & \text { Work life balance } \\
\text { - } & \text { Working conditions }\end{array}$ & $\begin{array}{l}\text { Balance between work and life, Self } \\
\text { ruling authority are considered to be } \\
\text { insignificant having poor relationship } \\
\text { with employee satisfaction whereas Pay } \\
\text { structure is not related with QWL. }\end{array}$ \\
\hline
\end{tabular}

It is concluded from the literature that QWL is a comprehensive concept consisting of several dimensions, tactics and prototypes with inter-related managerial and social extents (Rethinam and Ismail, 2007). Also it is understood from review that QWL studies have used various devices to quantify the status of employees QWL, but they amount for not more than $65 \%$ of total variance. Therefore there is a requirement for developing and validating Quality of Work Life Scale to measure the status of QWL.

\section{METHODOLOGY}

The study was conducted in forty textile industries where survey forms or responses were directed to 341 workers. Then EFA was applied to the data obtained from the records of the survey after responses from employees to lessen the questions and to validate the instrument, Confirmatory Factor Analysis (CFA) was done using
SPSS16. Further QWL model was generated using Structural Equation Modeling (SEM) to check the link between obtained components using Amos.

\subsection{Components selection}

Review of the literature resulted in 40 important Quality of Work Life dimensions obtained through repetitive usage by previous researchers in their study that accounted for the following dimensions like Work Environment, Work speed and routine, Task related interaction, Work complexity, Work life balance, Communication, Motivational insights, Encouragement of creative talent, Job Enrichment, Self control, Opinion about workload, opinion on working hours, Opinion about respect at workplace, Alternative work schedule, Job design, Implementing suggestion system, Healthy Working conditions,
Blue Eyes Intelligence Engineering \& Sciences Publication 


\section{Quality of Work Life - Development and Scale Validation for Textile Sectors in India}

Salary, Fair Compensation, Compensation and benefits, Relation and Co operation with co workers, Satisfaction with management, Socialization and realization, Human relations and Social integration, Grievance handling procedure, Safety Measures, Welfare measures, Transportation and rest time, Job security, Opportunity to develop human capabilities, Opportunity for career growth, Recognition, Personal growth and opportunity, Employee involvement in taking organizational decisions, satisfaction in Work, intrinsic satisfaction, Job Involvement, Training Programmes, Autonomy.

\subsection{Design of Questionnaire:}

Analysis of the research started with survey method adopted for study. The quantifying instrument were Questionnaires on Likert scale with five-point taken as "1" strongly disagree, "2" somewhat Agree, "3" Neutral, "4" Agree and "5" Strongly agree. The gauging tool considered reliant variable as QWL and 40 components of QWL were measured as self-regulating variables, it consists of 160 items. The tool consists of two sections. Demographical factors became the beginning part of the QWL tool followed by 160 items of 40 QWL components. To be impartial throughout survey few of items were intentionally negatively worded. The opinions of these responses were inversely counted. To upkeep the quality of questionnaire it was seen that the double barrel questions are dodged.

4.3 Major Quality of Work Life Components: In the current work, to check the dimensionalities of 160 items from 40 QWL components EFA was done and data was subjected to Principal Component Analysis, from varimax rotation, 6 chief factors were identified. This current work uses Exploratory Factor Analysis and resulted in 6 components having Eigen values greater than 1 which were taken into account consisting of Compensation, Work Environment, Relation and Cooperation, Job Security, Facility, Training and Development.

To confirm the adequacy of the responses collected KMO test was done. Here obtained KMO value is 0.772 , acceptable value as it greater than 0.6 , it is considered to be satisfactory (Kaiser and Rice, 1974). The values are proved to be substantial via Barlett's Test of Sphericity statistics (1890.736, dof. 105, Sig.0.000) proving an ample beginning for continuing with the analysis of factors.

Table 2. Results of KMO and Bartlett's Test results

\begin{tabular}{|c|c|c|}
\hline \multicolumn{3}{|c|}{ KMO and Bartlett's Test } \\
\hline \multicolumn{2}{|c|}{$\begin{array}{l}\text { Kaiser-Meyer-Olkin } \\
\text { Measure of Sampling } \\
\text { Adequacy. }\end{array}$} & .772 \\
\hline \multirow{3}{*}{$\begin{array}{l}\text { Bartlett's } \\
\text { Test of } \\
\text { Sphericity }\end{array}$} & $\begin{array}{l}\text { Approx. } \\
\text { Chi-Square }\end{array}$ & 3650.935 \\
\hline & $\mathrm{df}$ & 351 \\
\hline & Sig. & .000 \\
\hline
\end{tabular}

Table 2 represents the summary of Principal Component Analysis grounded on Exploratory Factor Analysis, all the 6 constituents having their Eigen value more than 1 were chosen for further analysis.

1. Compensation

\author{
2. Facilities and \\ 3. Job Security \\ 4. Relation and Co Operation \\ 5. Training and Development \\ 6. Work Environment
}

The unities obtained from factor analysis were studied to measure the implication of the statistics. The set of data was suitable as the obtained values are betweeen the range of 0.520 to 0.880 , the item loading is more than 0.5 , it puts forward that the data set was suitable. (Stewart 1981). 27 items were pulled out for final measurement tool on the grounds of several variables having a loading of atleast 0.5 . Table 4 summarized the extraction of six components through the factor analysis.

To check consistency of the tool alpha value was calculated the obtained Cronbach's alpha value is 0.875 , any Cronbach alpha value more than 0.7 is acceptable, as prescribed by Nunnally (1978). This made clear about the measuring device has good and reliable values that are applicable for further statistical computation.

Applying EFA to the first set of responses collected that measured item loadings of single item to pragmatically develop the QWL model. Eigen values were reviewed upon which six components had values more than 1 that together explained a variance of $61 \%$. 
Table 3 Summary of Principal Component Analysis

\begin{tabular}{|c|c|c|c|c|c|c|c|c|c|}
\hline \multicolumn{10}{|c|}{ Total Variance Explained } \\
\hline \multirow{2}{*}{$\begin{array}{l}\text { Com } \\
\text { pone } \\
\text { nt }\end{array}$} & \multicolumn{3}{|c|}{ Initial Eigenvalues } & \multicolumn{3}{|c|}{$\begin{array}{c}\text { Extraction Sums of Squared } \\
\text { Loadings }\end{array}$} & \multicolumn{3}{|c|}{$\begin{array}{l}\text { Rotation Sums of Squared } \\
\text { Loadings }\end{array}$} \\
\hline & Total & $\begin{array}{c}\text { \% of } \\
\text { Variance }\end{array}$ & $\begin{array}{l}\text { Cumulati } \\
\text { ve } \%\end{array}$ & Total & \begin{tabular}{c|} 
\% of \\
Variance
\end{tabular} & $\begin{array}{l}\text { Cumulativ } \\
\text { e \% }\end{array}$ & Total & \begin{tabular}{|c} 
\% of \\
Varianc \\
$\mathrm{e}$
\end{tabular} & \begin{tabular}{|c|} 
Cumul \\
ative \\
$\%$
\end{tabular} \\
\hline 1 & 4.775 & 17.686 & 17.686 & 4.775 & 17.686 & 17.686 & 3.988 & 14.771 & 14.771 \\
\hline 2 & 3.968 & 14.697 & 32.382 & 3.968 & 14.697 & 32.382 & 3.892 & 14.413 & 29.184 \\
\hline 3 & 2.604 & 9.646 & 42.028 & 2.604 & 9.646 & 42.028 & 2.516 & 9.317 & 38.501 \\
\hline 4 & 1.988 & 7.362 & 49.390 & 1.988 & 7.362 & 49.390 & 2.157 & 7.991 & 46.491 \\
\hline 5 & 1.730 & 6.408 & 55.798 & 1.730 & 6.408 & 55.798 & 2.135 & 7.909 & 54.400 \\
\hline 6 & 1.411 & 5.227 & 61.025 & 1.411 & 5.227 & 61.025 & 1.789 & 6.625 & 61.025 \\
\hline 7 & .929 & 3.440 & 64.465 & & & & & & \\
\hline 8 & .848 & 3.140 & 67.605 & & & & & & \\
\hline 9 & .816 & 3.024 & 70.628 & & & & & & \\
\hline 10 & .739 & 2.738 & 73.366 & & & & & & \\
\hline 11 & .714 & 2.643 & 76.009 & & & & & & \\
\hline 12 & .630 & 2.334 & 78.343 & & & & & & \\
\hline 13 & .598 & 2.214 & 80.558 & & & & & & \\
\hline 14 & .565 & 2.093 & 82.651 & & & & & & \\
\hline 15 & .519 & 1.924 & 84.575 & & & & & & \\
\hline 16 & .510 & 1.888 & 86.462 & & & & & & \\
\hline 17 & .485 & 1.797 & 88.259 & & & & & & \\
\hline 18 & .441 & 1.633 & 89.893 & & & & & & \\
\hline 19 & .412 & 1.527 & 91.419 & & & & & & \\
\hline 20 & .387 & 1.432 & 92.851 & & & & & & \\
\hline 21 & .362 & 1.341 & 94.192 & & & & & & \\
\hline 22 & .343 & 1.269 & 95.461 & & & & & & \\
\hline 23 & .310 & 1.149 & 96.610 & & & & & & \\
\hline 24 & .271 & 1.004 & 97.614 & & & & & & \\
\hline 25 & .249 & .924 & 98.537 & & & & & & \\
\hline 26 & .210 & .779 & 99.316 & & & & & & \\
\hline 27 & .185 & $\begin{array}{l}.684 \\
\end{array}$ & 100.000 & & & & & & \\
\hline
\end{tabular}

Table 4: Factor Analysis Summarized table

\begin{tabular}{|c|c|c|c|c|c|}
\hline Factors & Measurable values & Weights & Eigenvalues & Variance & Accumulated \\
\hline \multirow[t]{7}{*}{ Compensation } & Fair salary & .799 & \multirow{7}{*}{3.988} & \multirow{7}{*}{14.771} & \multirow{7}{*}{14.771} \\
\hline & Annual increments & .760 & & & \\
\hline & Allowances & .754 & & & \\
\hline & Wage Policies & .741 & & & \\
\hline & Fine & .736 & & & \\
\hline & Fair promotion Policy & .709 & & & \\
\hline & Rewards & .649 & & & \\
\hline \multirow{7}{*}{$\begin{array}{l}\text { Work } \\
\text { Environment }\end{array}$} & Working Conditions & .783 & \multirow{7}{*}{3.892} & \multirow{7}{*}{14.413} & \multirow{7}{*}{29.184} \\
\hline & Rules \& Regulations & .779 & & & \\
\hline & Self growth & .773 & & & \\
\hline & Work empowerment & .733 & & & \\
\hline & Motivational insights & .707 & & & \\
\hline & Work life balance & .680 & & & \\
\hline & Work Complexity. & .662 & & & \\
\hline \multirow{2}{*}{$\begin{array}{l}\text { Relation and } \\
\text { Cooperation }\end{array}$} & Harmonious relationship & .759 & \multirow[b]{2}{*}{2.516} & \multirow{2}{*}{9.317} & \multirow{2}{*}{38.501} \\
\hline & $\begin{array}{l}\text { Disputing and struggling } \\
\text { with workmates }\end{array}$ & .731 & & & \\
\hline
\end{tabular}

Published By:

Blue Eyes Intelligence Engineering \& Sciences Publication 
Quality of Work Life - Development and Scale Validation for Textile Sectors in India

\begin{tabular}{|c|c|c|c|c|c|}
\hline Factors & Measurable values & Weights & Eigenvalues & Variance & Accumulated \\
\hline & $\begin{array}{l}\text { Relationship with an } \\
\text { incompetent co-worker }\end{array}$ & .724 & & & \\
\hline & Support from sub ordinates & .679 & & & \\
\hline \multirow{3}{*}{$\begin{array}{l}\text { Job security/ } \\
\text { freedom }\end{array}$} & Secured Job & .812 & \multirow{3}{*}{2.157} & \multirow{3}{*}{7.991} & \multirow{3}{*}{46.491} \\
\hline & Work from home & .754 & & & \\
\hline & Conditions of job & .720 & & & \\
\hline \multirow[t]{4}{*}{ Facilities } & Medical Facilities & .806 & \multirow{4}{*}{2.135} & \multirow{4}{*}{7.909} & \multirow{4}{*}{54.400} \\
\hline & Safety measures & .682 & & & \\
\hline & Fringe benefits & .675 & & & \\
\hline & Transportation Facilities & .650 & & & \\
\hline \multirow[t]{2}{*}{$\begin{array}{l}\text { Training and } \\
\text { Development }\end{array}$} & $\begin{array}{l}\text { Sufficient Training } \\
\text { Programmes }\end{array}$ & .818 & \multirow{2}{*}{1.789} & \multirow{2}{*}{6.625} & \multirow{2}{*}{61.025} \\
\hline & $\begin{array}{l}\text { Outcome from Training } \\
\text { Programmes }\end{array}$ & 795 & & & \\
\hline
\end{tabular}

Table 5: Components of QWL in final measuring tool.

\begin{tabular}{|l|l|c|c|c|}
\hline $\begin{array}{l}\text { SI } \\
\text { No }\end{array}$ & $\begin{array}{l}\text { Components of } \\
\text { QWL }\end{array}$ & $\begin{array}{l}\text { Inquiry number } \\
\text { in the Survey } \\
\text { form }\end{array}$ & $\begin{array}{l}\text { Negative } \\
\text { Inquiry } \\
\text { number in the } \\
\text { Survey form }\end{array}$ & $\begin{array}{l}\text { Cronbach's } \\
\text { alpha value }\end{array}$ \\
\hline 1 & Compensation & $1,2,3,4,5,6,7$ & $2,5,7$ & 0.864 \\
\hline 2 & $\begin{array}{l}\text { Work } \\
\text { Environment }\end{array}$ & $8,9,10,11,12,13,14$ & $9,11,13,14$ & 0.791 \\
\hline 3 & $\begin{array}{l}\text { Relation and } \\
\text { Cooperation }\end{array}$ & $15,16,17,18$ & 16,17 & 0.785 \\
\hline 4 & $\begin{array}{l}\text { Job security/ } \\
\text { freedom }\end{array}$ & $19,20,21$ & 21 & 0.795 \\
\hline 5 & Facilities and & $22,23,24,25$ & 22,25 & 0.788 \\
\hline 6 & $\begin{array}{l}\text { Training } \\
\text { Development }\end{array}$ & 26,27 & 27 & 0.792 \\
\hline
\end{tabular}

0.902 are more than 0.9 and RMSEA $=0.071$ less than 0.08

4.4 QWL Components Validated through Confirmatory Factor Analysis.

The outcomes are authenticated from the results of EFA, Confirmatory factor Analysis (CFA) through Structural Equation Modeling (SEM) using AMOS software was done. QWL model consisting of six components was verified for authentication through CFA which resulted in six component of QWL model with 27 items and the factors are Compensation, Work Environment, Relation and Cooperation, Facilities, Job security, Training and Development. The first order 6 factor QWL measurement model revealed an adequate fit as shown in Figure 1. All the required fit indices namely Chi Square statistics was 100.704 with CMIN was 2.728 which is less than 3 , Goodness of fit index $=0.910$, Adjusted Goodness of fit Index $=0.900$, Normal Fit Index $=0.899$, Incremental Fit Index $=0.950$, Comparative Fit Index $=0.908$ with Tucker Lewis Index $=$ revealed acceptable and good values indicating good model fit.

\subsection{Convergent Validity:}

Cross validate the scale with another set of data sample through Convergent validity by assessing the loadings on items, Composite Reliability (CR) and Average Variance Extracted (AVE). It is explained as the degree of discrepancy shared between the items of identical concepts (Hair et. al., 2010). The value of CR must be 0.7 and above and AVE equal to .7 or above (Hair et al., 2006, p.777) to confirm the same. In current analysis, all the 6 factors of Quality of Work Life measurement model have AVE and CR value above the acceptable criterion and it is shown in the Table:7 and item loadings are indicated in Table 11. 


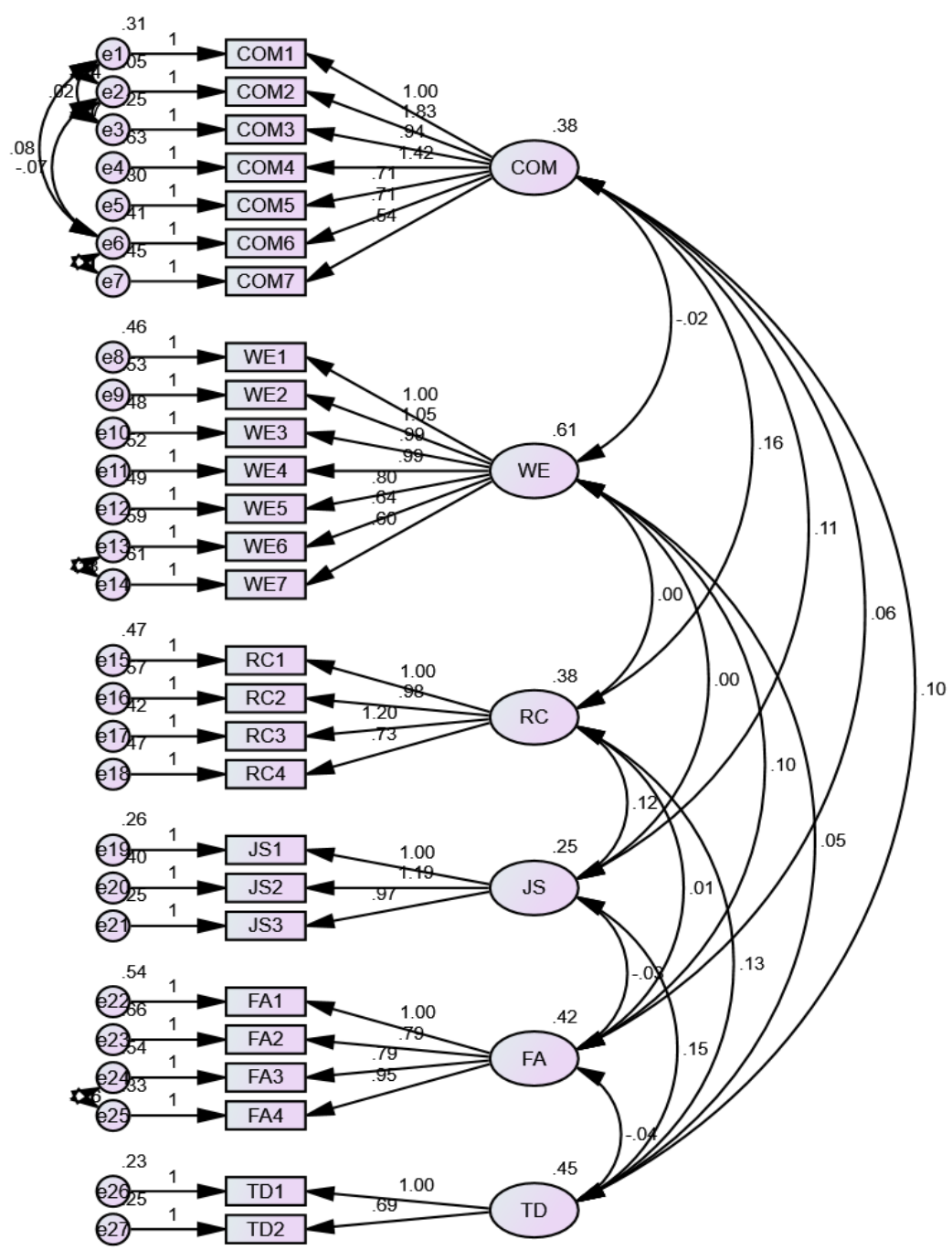

Fig 1: QWL Dimensional model

Table:6 Standardized Coefficient Estimates and $\mathbf{R}^{2}$ values of Measurement Model

\begin{tabular}{|c|c|c|c|c|c|c|c|}
\hline \multirow[t]{2}{*}{ Parameters } & \multicolumn{6}{|c|}{ QWL Components } & \multirow{2}{*}{$\begin{array}{c}\text { Acceptable } \\
\text { criterion range }\end{array}$} \\
\hline & C1 & C2 & C3 & $\mathrm{C4}$ & C5 & C6 & \\
\hline Estimates of Consistent factors & $\begin{array}{l}1.00 \\
1.83 \\
0.95 \\
1.42 \\
0.71 \\
0.71 \\
0.84\end{array}$ & $\begin{array}{c}1.00 \\
1.05 \\
0.99 \\
0.99 \\
0.8 \\
0.64 \\
0.60\end{array}$ & $\begin{array}{l}1.00 \\
0.98 \\
1.20 \\
0.73\end{array}$ & $\begin{array}{l}1.00 \\
1.19 \\
0.87\end{array}$ & $\begin{array}{l}1.00 \\
0.79 \\
0.79 \\
0.95\end{array}$ & $\begin{array}{l}1.00 \\
0.69\end{array}$ & $\begin{array}{l}\text { Convergent validity } \\
\text { is } \\
\text { showed if it is more } \\
\text { than } 0.30\end{array}$ \\
\hline Regression coefficient & $\begin{array}{l}0.31 \\
0.65 \\
0.25 \\
0.63 \\
0.30 \\
0.41 \\
0.45\end{array}$ & $\begin{array}{l}0.46 \\
0.63 \\
0.48 \\
0.62 \\
0.49 \\
0.69 \\
0.61\end{array}$ & $\begin{array}{l}0.47 \\
0.67 \\
0.42 \\
0.47\end{array}$ & $\begin{array}{l}0.26 \\
0.40 \\
0.25\end{array}$ & $\begin{array}{l}0.54 \\
0.66 \\
0.64 \\
0.33\end{array}$ & $\begin{array}{l}0.23 \\
0.25\end{array}$ & \\
\hline
\end{tabular}




\section{Quality of Work Life - Development and Scale Validation for Textile Sectors in India}

Table:7 Convergent Validity of QWL Model

\begin{tabular}{|l|c|c|}
\hline $\begin{array}{l}\text { Proposed Quality } \\
\text { of Work life } \\
\text { Components }\end{array}$ & $\begin{array}{l}\text { Comp } \\
\text { osite } \\
\text { Reliab } \\
\text { ility } \\
\text { (CR) }\end{array}$ & $\begin{array}{l}\text { Average Variance } \\
\text { Explained (AVE) }\end{array}$ \\
\hline Compensation & 0.892 & 0.542 \\
\hline Work Environment & 0.889 & 0.536 \\
\hline $\begin{array}{l}\text { Relation and } \\
\text { Cooperation security/ }\end{array}$ & 0.814 & 0.523 \\
\hline $\begin{array}{l}\text { Job ab } \\
\text { freedom and }\end{array}$ & 0.806 & 0.582 \\
\hline Facilities & 0.796 & 0.498 \\
\hline $\begin{array}{l}\text { Training } \\
\text { Development }\end{array}$ & 0.650 \\
\hline
\end{tabular}

\subsection{Discriminant Validity}

If the square root of AVE is greater than correlation values then discriminant validity is satisfied. (Sosik,2009). The Table:13 below indicate that square root of AVE values for all 6 factors are greater than its correlation value, thereby confirming Discriminant validity.

\section{Table: 8 Discriminant Validity of EC Measurement} Model

\begin{tabular}{|l|r|r|r|r|r|r|}
\hline & $C O M$ & $W E$ & $R C$ & $J S$ & $F A$ & $T D$ \\
\hline COM & $\mathbf{0 . 7 4}$ & & & & & \\
\hline WE & 0.21 & $\mathbf{0 . 7 3}$ & & & & \\
\hline RC & 0.29 & 0.20 & $\mathbf{0 . 7 2}$ & & & \\
\hline JS & 0.24 & 0.22 & 0.29 & $\mathbf{0 . 7 8}$ & & \\
\hline FA & 0.12 & 0.14 & 0.02 & 0.36 & $\mathbf{0 . 7 9}$ & \\
\hline TD & 0.14 & 0.06 & 0.19 & 0.33 & 0.47 & $\mathbf{0 . 7 5}$ \\
\hline
\end{tabular}

\section{CONCLUSION}

The existing work is an effort to design an QWL measuring instrument and authenticate the same. Through EFA six components of QWL were discovered they are: Compensation, Work Environment, Relation and Cooperation, Facilities, Job security, Training and Development. Later it disclosed that 6 types collectively explicated the total variance of $61 \%$.

Confirmatory factor analysis was done for next data set using 6 components that were taken out and authenticated for the device and they were: Compensation, Work Environment, Relation and Cooperation, Facilities, Job security, Training and Development. The aimed tool has shown both high reliability and legitimacy.

The scale developed in this study has its use restricted to textile sector. As per the availability of workforce and conditions in market different constituents may be added and deleted.

The outcome of the study and analysis will help the establishers and examiners to quantify the prominence of QWL in Textile sector.

\section{REFERENCES}

1. Aarthy, M., \& Nandhini, M. (2016). A study on quality of work life among the engineering college faculty members in Coimbatore District. International Journal of Management Research and Reviews, 6(8), 1051.
2. Ahmad, S. (2017). The Co-relation between QWL and Demographic Factors of Private University Employees in India. PEOPLE: International Journal of Social Sciences, 3(2).

3. Akter, K. M., \& Banik, S. (2018). Factors Affecting the Quality of Working Life: An Enquiry into the RMG Industry of Bangladesh. Journal of Human Resource Management, 6(1), 26-36.

4. Anyaoku, E. N. (2016). Demographic determinants of quality of work life of librarians working in Nigeria. International Journal of Advanced Library and Information Service, 4(1), 312-323.

5. Anyaoku, E. N. (2016). Demographic determinants of quality of work life of librarians working in Nigeria. International Journal of Advanced Library and Information Service, 4(1), 312-323.

6. Bagozzi, R. P., \& Phillips, L. W. (1982). Representing and testing organizational theories: A holistic construal. Administrative Science Quarterly, 27, 459-489.

7. Beloor, V., Nanjundeswaraswamy, T. S., \& Swamy, D. R. (2017) Employee Commitment and Quality of Work Life-A Literature Review. The International Journal of Indian Psychology, 4(2), 175-188.

8. Bolhari, A., Rezaeean, A., Bolhari, J., Bairamzadeh, S., \& Soltan, A. A. (2011). The relationship between quality of work life and demographic characteristics of information technology staffs.

9. Daud, N. (2012, May). The influence of quality of work life on organizational commitment: A study on academic staff in public institution of higher learning in Malaysia. In Innovation Management and Technology Research (ICIMTR), 2012 International Conference on (pp. 673-678). IEEE.

10. Dhamija, P., Gupta, S., \& Bag, S. (2019). Measuring of job satisfaction: the use of quality of work life factors. Benchmarking: An International Journal, 26(3), 871-892.

11. Elisaveta, S. (2006). Relationship among perceptions of quality of work life and job satisfaction. Management and Organization Review, 2(3), 459-460.

12. ellah Mejbel, A. A., Almsafir, M. K., Siron, R., \& Mheidi, A. S. (2013) The drivers of Quality of Working Life (QWL): A critical review. Australian Journal of Basic and Applied Sciences, 7(10), 398-405.

13. Gupta, B. (2015). An empirical study of impact of demographic variables on quality of work life among insurance sector employees in Indore Division. Pacific Business Review International, 8(1), 24-32.

14. Hair, J. F., Black, W. C., Babin, B. J., Anderson, R. E., \& Tatham, R. L. (1998). Multivariate data analysis (Vol. 5, No. 3, pp. 207-219). Upper Saddle River, NJ: Prentice Hall.

15. Haque, M. E., Rana, M. S., \& Abedin, M. Z. (2015). Assessing the Quality of Work Life of Garment Workers in Bangladesh: A Study on Garment Industries in Dhaka City. Global Journal of Management And Business Research.

16. Hosmani, A., \& Shambhushankar, B. (2014). Study on Impact of Quality of Work Life on Job Performance amongst Employees of Secunderabad Division of South Central Railway. Research Journal of Managemnet Sciences, 3(11), 8-11.

17. Indumathy, R. (2012). A study on quality of work life among workers with special reference to textile industry in Tirupur district--A textile hub. Journal of Contemporary Management Research.issue xii.

18. Jumbulingam, D. E. S. (2015). Relationship between Demographic variables and Quality of Work life, Professionals in Information Technology Chennai. Innovative Journal of Business and Management, 4(02), 42-44.

19. Kaiser, H. F., \& Rice, J. (1974).Little jiffy, Mark IV. Educational and psychological measurement, 34(1), 111-117.

20. Kanakarathinam, R. (2016). Quality of Work Life of Textile Employees-With Special Reference to Tirupur District, Tamilnadu, India. International Journal of Engineering and Management Research (IJEMR), 6(3), 602-606.

21. Kang, L. S., \& Deepak. (2013). Determinants of Quality of Work Life: A Case of Veterinary Doctors in Punjab. Management and Labour Studies, 38(1-2), 25-38.

22. MANDAVIYA, M. (2013). A STUDY ON PERCEPTION OF QUALITY OF WORK LIFE AMONG TEXTILE INDUSTRY WORKERS IN GUJARAT. CLEAR International Journal of Research in Commerce \& Management, 4(8).

23. Mebarki, B., Fouatih, A., El Amine, M., \& Mokdad, M. (2019). Quality of Work Life and differences in demographic characteristics among managerial staff in Algerian tertiary sector. Work, 62(3), 435-442. 
24. Mehrotra, R., \& Khandelwal, V. (2015). Association of Demographic Variables (Gender and Salary) On Quality of Work Life of Teaching Employees in Private Technical Institutions in Bareilly Region. International Journal of Education and Science Research Review, 2(2), 01-06.

25. Nanjundeswaraswamy, T. S., \& Swamy, D. R. (2015). An Empirical Research on the Relationship. Bangladesh Sociological Society, 12(1), 41.

26. Nanjundeswaraswamy, T. S., Beloor, V., Swamy, D. R., \& Nagesh, P. (2019). Empirical Study on Effect of Welfare Facilities on Job Satisfaction. Advances In Management Vol, 12, 1.

27. Narehan, H., Hairunnisa, M., Norfadzillah, R. A., \& Freziamella, L. (2014). The effect of quality of work life (QWL) programs on quality of life (QOL) among employees at multinational companies in Malaysia. Procedia-Social and Behavioral Sciences, 112, 24-34.

28. Nayak, T., Sahoo, C. K., \& Mohanty, P. K. (2015). Quality of work life plays the mediating role in between workplace empowerment and employee commitment: a study on healthcare employees of an Indian state.

29. Nunnally, J.C (1978), Psychometric theory (2nd ed.) New York, McGraw Hill

30. RAMACHANDRAN, A. A STUDY ON QUALITY OF WORK LIFE OF EMPLOYEES IN PRIVATE COMPANIES WITH SPECIAL REFERENCE TO ERNAKULAM DISTRICT. Age, 40(10), 80.

31. Rathamani, P., \& Ramchandra, R. (2013). A study on quality of work life of employees in textile industry-Sipcot, Perundurai. IOSR Journal of Business and Management (IOSR-JBM), e-ISSN, 54-59.

32. Roopa, A. V., \& Narayanan, T. (2014). Quality of Working Life and Job Behavior of Workers in IT Industry: A Comparative Study of Private and Public Sectors. Research Journal of Applied Sciences, Engineering and Technology, 8(9), 1061-1065.

Annexure 1

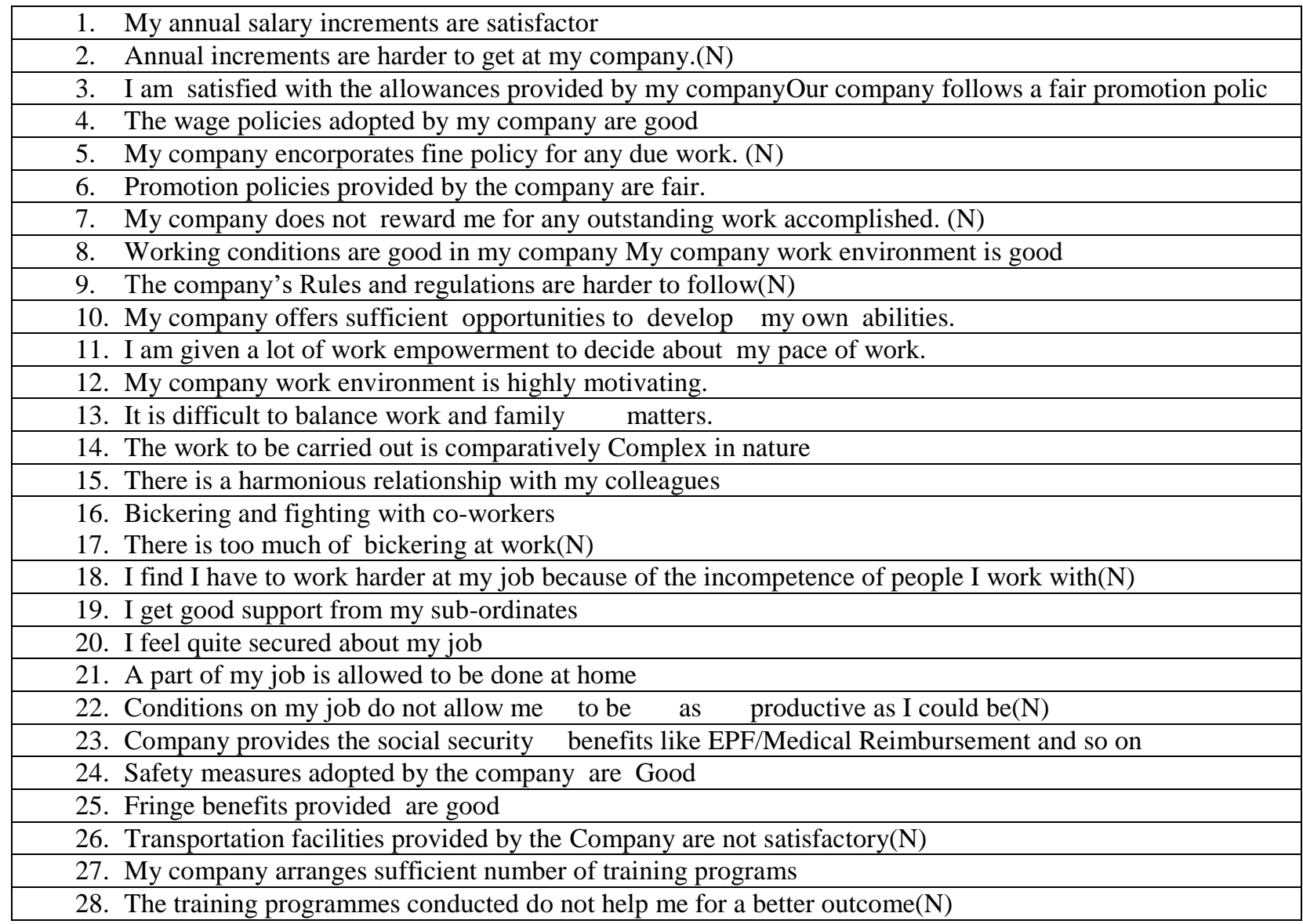

33. Rose, R. C., Beh, L., Uli, J., \& Idris, K. (2006). Quality of work life: Implications of career dimensions. Journal of Social Sciences, 2(2), 61-67.

34. RS, M. (2018). Impact Of Welfare Measures On The Quality Of Work Life Of Employees In Cooperative And Private Sugar Mills In Tamil Nadu.

35. Rubel, M. R. B., \& Kee, D. M. H. (2014). Quality of work life and employee performance: Antecedent and outcome of job satisfaction in Partial Least Square (PLS). World Applied Sciences Journal, 31(4), 456-467.

36. Sinha, C. (2012). Factors affecting quality of work life: Empirical evidence from Indian organizations. Australian Journal of Business and Management Research, 1(11), 31-40.

37. Stewart, D. W. (1981). The application and misapplication of facto analysis in marketin research. Journal of Marketing Research, 51-62.

38. Subhashini, S., \& Gopal, C. R. (2013). Quality of work life among women employees working in garment factories in coimbatore district. Asia pacific journal of research vol: i

39. Swamy, D. R., Nanjundeswaraswamy, T. S., \& Rashmi, S. (2015) Quality of work life: scale development and validation. International Journal of Caring Sciences, 8(2), 281.

40. Yadav, R., \& Khanna, A. (2014). Literature review on quality of work life and their dimensions. IOSR Journal Of Humanities And Social Science (IOSR-JHSS) Volume, 19, 71-80.

41. Zare, M. H., Ahmadi, B., Sari, A. A., Arab, M., \& Kor, E. M. (2012) Quality of working life on residents working in hospitals. Iranian journal of public health, 41(9), 78. 


\section{Quality of Work Life - Development and Scale Validation for Textile Sectors in India}

\section{AUTHORS PROFILE}

Vanishree Beloor working as Assistant Professor, Dept of Industrial Engg and Management, JSSATE, Bengaluru, Karnataka. India. Her area of expertise includes Production Management, Human Resource Management, Organizational Behavior and is Carrying out research in the field of Mechanical sciences.

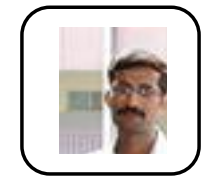

Dr. T S Nanjundeswaraswamy is Associate Professor, Mechanical Engineering Department, at JSS Academy of Technical Education, Bangalore, Karnataka, India. His areas of expertise include Probability and Statistics, Simulation Modeling, Operations management, human more than 15years of teaching and research experience.

Dr. Swamy D R is Dean (Research) and Professor of Industrial Engineering and Management in the Department of IE\&M, at JSS Academy of Technical Education, Bangalore, Karnataka, India. His areas of expertise include engineering management, quality engineering, human resource management. He is the author of several technical journal articles. He is a member of several professional associations and he has a rich research experience of more than 20 years. He has many funded projects and consultancy activities. 